Research Article

\section{Prospective study of pain and psychological symptoms of first- year university students}

\author{
Airi Oksanen ${ }^{1 *}$, Katri Laimi ${ }^{1}$, Eliisa Löyttyniemi ${ }^{2}$ and Kristina \\ Kunttu ${ }^{3}$ \\ ${ }^{1}$ Department of Physical Rehabilitation and Medicine, Turku University Hospital and University of \\ Turku, Turku, Finland \\ ${ }^{2}$ Department of Biostatistics, University of Turku, Turku, Finland \\ ${ }^{3}$ Finnish Student Health Service, Turku, Finland
}

\section{Abstract}

Background: Even if pain and psychological symptoms experienced by university students are common, the prognosis of these symptoms is unknown.

Objective: To examine the incidence and the outcome of frequent musculoskeletal and psychological symptoms in a 4-year follow-up of first-year university students.

Methods: In 2008 , a national random sample $(\mathrm{N}=2750)$ of Finnish university students completed a questionnaire concerning pain and psychological symptoms. Of the 416 first-year students, 123 responded to the same questionnaire also in their fourth study year in 2012.

Results: Of the first-year university students with frequent pain or psychological symptoms, one half $(47 \%-65 \%)$ reported frequent symptoms also four years later. Almost all $(78 \%-95 \%)$ of the symptom-free first-year students were symptom-free also in their fourth study year.

Conclusion: Our findings indicate that pain and psychological symptoms in university students are rather persistent during the first four study years. On the other hand, as half of those with frequent symptoms become symptomless and as the prognosis of symptom-free students is favourable, there is still need for further cohort studies on this issue.

\section{More Information}

*Address for Correspondence: Airi Oksanen, Department of Physical Rehabilitation and Medicine, Turku University Hospital and University of Turku, P.O. Box 28, Fl-20701, Turku, Finland, Tel: 358-2-3131996; Fax: +358-2-3133730; Email: airi.oksanen@tyks.fi

Submitted: January 19, 2021

Approved: February 09, 2021

Published: February 10, 2021

How to cite this article: Oksanen A, Laimi K, Löyttyniemi E, Kunttu K. Prospective study of pain and psychological symptoms of first-year university students. J Nov Physiother Rehabil. 2021; 5: 001-004.

DOI: 10.29328/journal.jnpr.1001038

Copyright: @ 2021 Oksanen A, et al. This is an open access article distributed under the Creative Commons Attribution License, which permits unrestricted use, distribution, and reproduction in any medium, provided the original work is properly cited.

Keywords: University students; Pain; Psychological symptoms; Prospective study; Outcome

Check for updates

OPEN ACCESS

\section{Introduction}

A slightly increasing trend of frequent pain and psychological symptoms has been shown both in Finnish adolescents and in university students during the past decades [1-4]. In university students, the prevalence of weekly neck pain increased from $25 \%$ to $29 \%$, low back pain from $10 \%$ to $14 \%$ and overall psychological distress from $22 \%$ to $28 \%$ during the period from 2000 to 2012 $[3,4]$. In cross-sectional studies comparing the prevalence of both pain and psychological symptoms in adolescents and young adults, these symptoms have mostly been reported to increase with age [2-7]. The university entry is potentially a vulnerable and demanding period with long-lasting health consequences. In this transitional phase from adolescence to adulthood, students may be more prone to experience increased psychological distress and general health problems $[8,9]$. These health problems have been regarded important to be taken into account in the first study year for the purpose of preventing health problems in the later phase of the studies and mainting ones's studying capacity and future working ability.

To our knowledge, however, the prognosis of different pain and psychological symptoms especially in university students has not previously been studied using a prospective study design. The aim of our study was to examine the incidence and outcome of pain and psychological symptoms in a fouryear follow-up study of first-year university students. Our hypothesis was that both frequent pain and psychological symtoms including overall psychological distress in Finnish university students increase significantly from the first study year to the fourth study year.

\section{Subjects and methods}

The data for present study were derived from a nationwide 
health survey conducted at four-year intervals among Finnish university students (Student Health Survey, N=128 600152196 per year in 2000-2012). The study population has been described earlier [3]. In Finland, all full-time university students are entitled to receive health care services provided by the Finnish Student Health Service (FSHS). The FSHS registers were used for a systematic sampling of the study population. This study was designed as a prospective cohort study of first-year students. The students have received prior written information on the follow-up study. Those first-year students who answered the first questionnaire in 2008 were specially invited and asked to re-fill the questionnaire second time in 2012.

In 2008, a random sample $(\mathrm{N}=4983)$ of all 19-34-yearold undergraduate students $(\mathrm{N}=152$ 196) received a selfadministered questionnaire. The participation rates of this follow-up study are shown in a flow chart (Figure 1).

The methodology of this nationwide student health survey has been described previously $[3,10,11]$. The present study focused on a prospective cohort of first-year university students.

The questionnaire both at baseline year 2008 and in the follow-up year 2012 consisted of items of physical, mental and social health. The frequency of pain (neck, low back, limb or joint pain, headache) and of psychological symptoms (depressiveness, anxiety, concentration problems, psychological tension) during the past month were categorized to "no symptoms" (never; occasionally), and "frequent symptoms" (weekly; daily) [3,10,11].

The General Health Questionnaire (GHQ-12) was used to rate the students' overall psychological distress within the past weeks [12]. The measure includes questions regarding

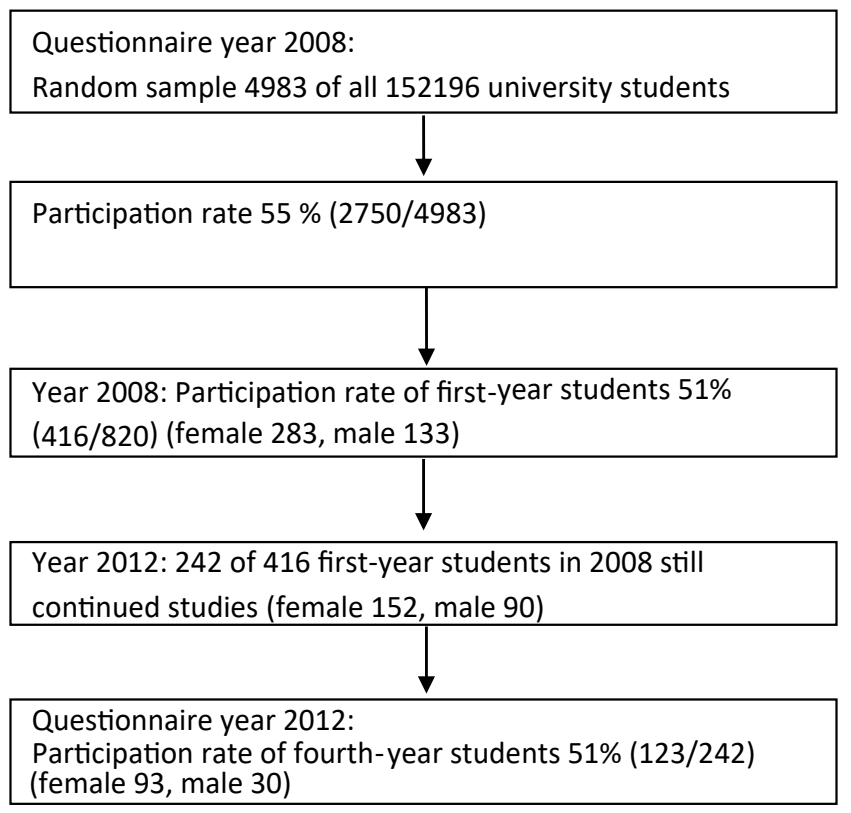

Figure 1: Flow chart of the university student population. the respodents' current life. Responses for all 12 symptoms were scored as 0: "no problem" (not at all; same as usual), and 1: "problem" ("somewhat more than usual"; "much more than usual"). The score 4-12 is considered as an indication of psychological distress $[13,14]$.

\section{Statistical analysis}

Descriptive values are expressed as frequencies and percentages. Changes in pain and psychological symptoms were analyzed using the proportional-odds cumulative logit model for repeated measures, since the same students participated twice. In the model, overall differences between genders were tested, and changes over time and the gender $x$ time interaction were also included to find possible gender differences in changes over time. $p$ - values (two-tailed) less than 0.05 were considered as statistically significant. Statistical analyses were conducted using SAS for Windows, version 9.3 (SAS Institute, Cary, NC, USA). The study design and the informed consent procedures were approved by the Joint Ethics Review Committee of the Turku University Medical Faculty and the Turku University Central Hospital.

\section{Results}

In 2008, a total of 820 of the 2750 respondents (female $\mathrm{N}=1750$, male $\mathrm{N}=1000$ ) were first-year students, and of them, 416 (female $\mathrm{N}=283$, male $\mathrm{N}=133$ ) answered the first questionnaire. Of these 416 students, 242 still continued their studies four years later, and were invited to follow-up study in 2012. Fifty one percent $(123 / 242$; female $N=93$, male $N=30)$ agreed to participate and re-filled the questionnaire second time in their fourth study year.

Table 1 shows the 4-year persistence and the incidence of symptoms from the first to the fourth study year. Of the first-year students with frequent symptoms in 2008, one half (47\% - 65\%) still reported that they had the same frequent symptoms in their fourth study year. The most permanent symptoms were neck pain, psychological tension and overall psychological distress. of the headache-free first-year students $20 \%(p<0.05)$ reported frequent headache in the follow-up. The majority $(78 \%-95 \%)$ of the symptom-free first-year students remained symptom-free in the follow-up as well.

\section{Discussion}

To our knowledge, this is the first prospective outcome study of university students with and without frequent pain or frequent psychological symptoms. The prognosis of symptoms was better than we suspected. It was surprising that the incidence of new symptoms was low. On the other hand, perceived symptoms of the students including overall psychological distress was remained quite persistent from the first study year to the four-year follow-up.

Even if previous cross-sectional studies have raised a 
Table 1: Outcome of frequent symptoms and symptom-free situation of first-year students (year 2008) in their fourth study year (2012).

\begin{tabular}{|c|c|c|c|}
\hline \multirow[b]{2}{*}{ Year 2008} & \multirow[b]{2}{*}{$\mathbf{N}(100 \%)$} & \multicolumn{2}{|c|}{ Year 2012} \\
\hline & & No symptoms N (\%) & Frequent symptoms (\%) \\
\hline \multicolumn{4}{|l|}{ Neck pain (NP) } \\
\hline No NP & 91 & $71(78)$ & $20(22)$ \\
\hline Frequent NP & 31 & $11(35)$ & $20(65)$ \\
\hline \multicolumn{4}{|l|}{ Low back pain (LBP) } \\
\hline No LBP & 104 & $90(87)$ & $14(13)$ \\
\hline Frequent LBP & 16 & $8(50)$ & $8(50)$ \\
\hline \multicolumn{4}{|l|}{$\begin{array}{l}\text { Limb or joint pain } \\
\text { (LJP) }\end{array}$} \\
\hline No LJP & 110 & $105(95)$ & $5(5)$ \\
\hline Frequent LJP & 9 & $4(44)$ & $5(56)$ \\
\hline \multicolumn{4}{|l|}{ Headache (HA) } \\
\hline No HA & 105 & $84(80)$ & $21(20)^{\star}$ \\
\hline Frequent $\mathrm{HA}$ & 16 & $8(50)$ & $8(50)$ \\
\hline \multicolumn{4}{|l|}{ Depressiveness (De) } \\
\hline No De & 97 & $89(92)$ & $8(8)$ \\
\hline Frequent De & 24 & $12(50)$ & $12(50)$ \\
\hline \multicolumn{4}{|l|}{ Anxiety (An) } \\
\hline No An & 102 & $90(88)$ & $12(12)$ \\
\hline Frequent An & 19 & $10(53)$ & $9(47)$ \\
\hline \multicolumn{4}{|l|}{$\begin{array}{l}\text { Concentration } \\
\text { problems }(C p)\end{array}$} \\
\hline No (Cp) & 99 & $85(86)$ & $14(14)$ \\
\hline Frequent (Cp) & 22 & $9(41)$ & $13(59)$ \\
\hline \multicolumn{4}{|l|}{$\begin{array}{l}\text { Psychological tension } \\
(\mathrm{Pt})\end{array}$} \\
\hline No Pt & 96 & $81(84)$ & $15(16)$ \\
\hline Frequent Pt & 25 & $9(36)$ & $16(64)$ \\
\hline $\begin{array}{l}\text { Overall psychological } \\
\text { distress (GHQ-12) }\end{array}$ & & $\begin{array}{l}\text { No distress } \\
\text { symptoms }\end{array}$ & Distress symptoms \\
\hline No distress & 92 & $75(82)$ & $17(18)$ \\
\hline Distress & 28 & $11(39)$ & $17(61)$ \\
\hline
\end{tabular}

question of possible poor prognosis of symptoms in student populations [1-4], this suspicion was not confirmed by our prospective study of first-year students. Only half of frequent symptoms were reported to persist after four years, while another half had alleviated. On the other hand, the incidence of new frequent symptoms was evident only in less than a quarter, while most of symptom-free students remained symptom-free four years later for all symptoms. The study with university population has also demonstrated mild musculoskeletal complains at baseline and overall stable course during one year follow-up [15]. On the other hand, Liu, et al. reported in their recent longitudinal four-year study in a Chinese context that there were differences in the psychological health states of different years. Especially the depression, anxiety, and stress all appeared in the first or second year, but some improvements were achieved in the third and last years [16]. It seems possible that pain and psychological symptoms during the first four years are transient without a clear sign of chronification. Our study design does not, however, allow for the estimation of previous adolescent years. Even if our study population was nationally representative, our results remain suggestive due to the low number of first-year students. The most likely reason for low response rate was the extensive and demanding questionnaire including altogether 168 questions of f.ex. physical, mental, social health and health behavior. It is also possible that the timing of data collection in the spring when students are busy with their studies and exams was not favorable for this student group. In a small study population, the risk of bias is always possible, despite of all efforts to keep study phases and questionnaires identical. Due to the selection effect the true course might not be so favorable than the results suggest.

Because of the surprising results in our study population, other prospective studies are needed in order to confirm the results and to describe the impact of these symptoms on students' life. Moreover, identification of possible risk groups of students could help in designing effective prevention interventions.

\section{Conclusion}

Our findings indicate that pain and psychological symptoms in university students are rather persistent. On the other hand, half of those with frequent symptoms become symptomless and prognosis of symptom-free students is favorable. This finding emphasizes need for further cohort studies on the subject.

\section{Acknowledgements}

We would like to thank the universities, students and personnel of the Finnish Student Health Service participating in the health surveys.

\section{Disclosure}

The paper was prepared without external funding and the authors declare no conflicts of interest.

\section{Author contributions}

A.O. is responsible for conception, design, data acquisition, analysis and interpretation of data, drafting, revision, and final approval of the version.

K.L. is responsible for conception, design, data acquisition, analysis and interpretation of data, drafting, revision, and final approval of the version.

E.L. is responsible for design, statistical analysis, drafting, revision, and final approval of the version.

K.K. is responsible for conception, design, data acquisition, analysis and interpretation of data, drafting, revision, and final approval of the version.

All authors discussed the results and commented on the manuscript.

\section{References}

1. Vikat A, Rimpelä $M$, Salminen JJ, Rimpelä A, Savolainen A, et al. Neck or shoulder pain and pain of the lower back among Finnish 
adolescents. Scand J Public Health. 2000; 28: 164-173.

PubMed: https://pubmed.ncbi.nlm.nih.gov/11045747/

2. Hakala P, Rimpelä A, Salminen JJ, Virtanen SM, Rimpelä M. Back, neck, and shoulder pain in Finnish adolescents: national cross sectional surveys. BMJ. 2002; 325: 743.

PubMed: https://pubmed.ncbi.nlm.nih.gov/12364301/

3. Oksanen AM, Laimi K, Löyttyniemi E, Kunttu K. Trends of weekly musculoskeletal pain from 2000 to 2012: National study of Finnish university students. Eur J Pain. 2014; 18: 1316-1322.

PubMed: https://pubmed.ncbi.nlm.nih.gov/24687865/

4. Oksanen AM, Laimi K, Björklund K, Löyttyniemi E, Kunttu KA. 12 -Year Trend of Psychological Well-being: National Study of Finnish University Students. 2016. Cent Eur J Public Health. 2017; 25: 113-119.

5. Alricsson M, Landstad BJ, Romild U, Werner S. Self-related health, physical activity and complaints in Swedish high school students. Scientific World J. 2006; 18: 816-826.

PubMed: https://www.ncbi.nlm.nih.gov/pmc/articles/PMC5917311/

6. Alricsson M, Domalewski D, Romild U, Asplund R. Physical activity, health, body mass index, sleeping habits and body complaints in Australian senior high school students. Int $\mathrm{J}$ Adolesc Med Health. 2008; 20: 501-512.

PubMed: https://pubmed.ncbi.nlm.nih.gov/19230450/

7. Ebrahimi M, Dashti $H$, Mehrabkhani $M$, Arghavani $M$, DaneshvarMozafari A. Temporomandibular Disorders and Related Factors in a Group of Iranian Adolescents: A Cross-sectional Survey. J Dent Res Dent Clin Dent Prospects. 2011; 5: 123-127.

PubMed: https://www.ncbi.nlm.nih.gov/pmc/articles/PMC3442434/

8. Dyrbye LN, Thomas MR, Shanafelt TD. Systematic review of depression, anxiety, and other indicators of psychological distress among U.S. and Canadian medical students. Acad Med. 2006; 81: 354-373. PubMed: https://pubmed.ncbi.nlm.nih.gov/16565188/

9. Verger P, Combes JB, Kovess-Masfety V, Choquet M, Guafliardo V, et al. Psychological distress in first year university students: socioeconomic and academic stressors, mastery and social support in young men and women. Soc Psych Psych Epid. 2009; 44: 643-650. PubMed: https://pubmed.ncbi.nlm.nih.gov/19096741/

10. Kunttu K, Huttunen T. Student Health Survey 2008: a national survey among Finnish university students. Ylioppilaiden terveydenhoitosäätiön tutkimuksia Publication No 45. Helsinki: Finnish Student Health Service, Ylioppilaiden terveydenhoitosäätiö (In Finnish). 2009.

11. Kunttu K, Pesonen T. Student Health Surevey 2012: a national survey among Finnish university students. Ylioppilaiden terveydenhoitosäätiön tutkimuksia Publication No 47. Helsinki: Finnish Student Health Service, Ylioppilaiden terveydenhoitosäätiö (In Finnish). 2013.

12. Goldberg $D$. The detection of psychiatric illness by questionnaire: A technique for the identification and assessment of non-psychotic psychiatric illness. London, New York: Oxford University Press. 1972.

13. Holi MM, Niarttunen M, Ahlberg V. Comparison of the GHQ-36, the GHQ-12 and the SCL -90 as psychiatric screening instruments in the Finnish population. Nord J Psychiat. 2003; 57: 233-238.

14. Penninkilampi-Kerola V, Miettunen J, Ebeling H. A comparative assessments of the factor structures of psychometric properties of the GHQ-12 and the GHQ-20 based on data from Finnish populationbased sample. Scand J Psychol. 2006; 47: 431-440.

PubMed: https://pubmed.ncbi.nlm.nih.gov/16987212/

15. Bruls VE, Jansen NW, van Kuijk SM, Kant IJ, Bastiaenen HG. The course of complaints of arm, neck and/or shoulder: a cohort study in a university population participating in work or study. BMJ Musculoskelet Disord. 2018; 19: 1-17.

PubMed: https://pubmed.ncbi.nlm.nih.gov/29960589/

16. Liu X, Ping S, Gao W. Changes in Undergraduate Students' Psychological Well-Being as They Experience University Life. Int J Environ Res Public Health. 2019; 16: 2864.

PubMed: https://pubmed.ncbi.nlm.nih.gov/31405114/ 